To Maega | Jurnal Pengabdian Masyarakat

Oktober 2021, Vol.4, No.3, hal, 363-376

$\operatorname{ISSN}(P): 2622-6332 ; \operatorname{ISSN}(E): 2622-6340$

http://www.ojs.unanda.ac.id/index.php/tomaega

\title{
Pelatihan Strategi Pemasaran Online Untuk Pedagang yang Terdampak Covid19 di Surabaya dan Sekitarnya
}

\author{
Adinda Alifia Putri ${ }^{1 *}$, Aura Iman Aisyah ${ }^{1}$, Danniel Adhis Putra Pratama1, \\ Elgiva Nariswari ${ }^{1}$, Gangsar Priambodo ${ }^{1}$, Gracie Virginia ${ }^{1}$, Rahma Dianti ${ }^{1}$, \\ Johanna Natalia ${ }^{1}$ \\ ${ }^{1}$ Psikologi, Fakultas Psikologi, Universitas Surabaya \\ *Correspondent Email: johannanatalia@gmail.com
}

\author{
Article History:
}

Received: 19-09-2021; Received in Revised: 30-09-2021; Accepted: 21-09-2021

DOI: http://dx.doi.org/10.35914/tomaega.v3i2.864

\begin{abstract}
Abstrak
COVID19 memberikan banyak dampak yang negatif terhadap dunia tak terkecuali Indonesia. Sebagai penanggulangan COVID19, pemerintah memberlakukan peraturan baru bernama PPKM. Salah satu dampak negatif dari PPKM adalah menurunnya perekonomian nasional secara signifikan. Pelaku Pedagang Kaki Lima (PKL) menjadi salah satu sosok yang terdampak sistem PPKM karena mengalami penurunan omset diakibatkan oleh menurunnya jumlah pembeli dan diberlakukannya jam malam yang membuat mereka tidak bisa berjualan hingga jam yang telah ditentukan. Metode yang digunakan dalam pelatihan ini adalah pendidikan masyarakat dengan tujuan memberikan pemahaman dan kesadaran mengenai kemajuan iptek yang telah meningkat sehingga pelaku UMKM dapat memanfaatkan sistem penjualan online. Evaluasi kegiatan ini menggunakan metode survei, yang dilaksanakan secara dua kali, yaitu pada sebelum pemberian materi (pretest) dan setelah pemberian materi (posttest) Hasil yang terlihat adalah adanya peningkatan pemahaman (kognitif) para pedagang mengenai sistem penjualan online.
\end{abstract}

Kata Kunci: COVID19, PKL, PPKM, online, omset.

\section{Abstract}

COVID19 has had many negative impacts on the world, conquered by Indonesia, as a response to COVID-19, the government issued a new regulation called PPKM. One of the negative impacts of PPKM is a significant decline in the national economy. Pedagang Kaki Lima (PKL) are one of the figures who created the PPKM system because they experienced a decline in turnover caused by a decrease in buyers and the imposition of a curfew that prevented them from selling until the appointed hour. The method used in this training is public education to provide understanding and awareness about the progress of technology that has increased so that UMKM can take advantage of the online sales system. The evaluation of this activity uses survey method, which is carried out twice, namely before giving the material (pretest) and after giving the material (posttest). The visible result is an increase in the understanding (cognitive) of businessmen regarding the online sales system.

Keyword: COVID19, PKL, PPKM, online, omset. 


\section{Pendahuluan}

UMKM adalah satu diantara macam usaha yang memiliki peran cukup penting untuk pertumbuhan ekonomi yang ada di Indonesia (Aisyah, 2020). Menurut Tambunan (2002), jika melihat sepuluh tahun terakhir ini, pertumbuhan jumlah unit UMKM tahun 2016 - 2019 mengalami kenaikan sebanyak 4,2\% setiap tahunnya serta rata-rata kontribusi UMKM kepada Produk Domestik Bruto (PDB) Indonesia 3 tahun diatas 50\%. Hal tersebut membuktikan bahwa UMKM mampu meningkatkan sektor perekonomian masyarakat Indonesia dengan mandiri dan juga menunjang laju pertumbuhan pertumbuhan ekonominya, oleh sebab itu UMKM menjadi salah satu diantara banyak usaha yang diunggulkan oleh Bank Indonesia (Aisyah, 2020).

Dalam upaya meningkatkan perekonomian dimasa krisis pandemi ini adalah pemerintah mencoba mendorong sektor UMKM karena banyak pekerja yang terlibat langsung (Bahtiar, 2021). Selain adanya UMKM juga ada sektor UKM yakni Usaha Kecil Menengah yang punya andil penting dalam pembangunan perekonomian di Indonesia (Siegel, 2000). Hal ini disebabkan karena Indonesia memiliki jumlah penduduk yang berpendidikan rendah dan mencari nafkah hidup melalui kegiatan usaha kecil baik di sektor tradisional maupun modern. Pada pembangunan perekonomian nasional UKM memiliki andil yang besar, sehingga selain berperan pada pertumbuhan ekonomi serta penyerapan tenaga kerja juga berperan pada perindustrian beberapa hasil pembangunan (Wijoyo, 2020).

UKM yang dimaksud yakni suatu usaha yang memiliki karyawan atau pegawai yang jumlahnya tidak lebih dari 50 orang dan berdasarkan UndangUndang Nomor 9 Tahun 1995 memiliki kekayaan bersih paling banyak Rp200 juta (di luar tanah dan bangunan) serta penjualan yang dimiliki paling banyak Rp1 M (Tambunan, 2002). Usaha kecil biasanya yakni perusahaan perorangan, contohnya restoran lokal, warung, pengusaha konstruksi lokal, laundry, dan pedagang kaki lima (PKL) serta terdapat juga usaha musiman yang berarti usaha yang hanya menggantungkan penjualan pada beberapa musim (Wijoyo, 2020)

Dalam sektor jasa, UKM dinilai bisa menjadi usaha untuk masa mendatang yang dapat menumbuhkan perekonomian serta daya saing sehingga pada tiap tahunnya dapat mengalami perkembangan seiring dengan perubahan gaya hidup, inovasi dalam bisnis dan pekerjaan, serta kebutuhan hidup yang mengarah pada aspek praktis dan serba cepat (Richards, 2008). Disamping itu salah satu jenis usaha jasa yang semakin berkembang dan inovatif di salah satu UMKM yang berkembang pesat dalam 5 tahun terakhir ini adalah usaha makanan kecil-kecilan seperti PKL dan Warkop. Namun kedua jenis UMKM ini relatif nyaris belum terjamah oleh binaan dan suntikan dana Bank (Abidin, 2015).

Sejak akhir tahun 2019 hingga sekarang dunia masih dilanda oleh pandemi COVID-19 termasuk Indonesia. Pandemi ini telah ditetapkan oleh WHO sebagai situasi gawat darurat dikarenakan memiliki potensi dampak yang besar terhadap berbagai sektor kehidupan, yakni pada sektor kesehatan, pendidikan, pariwisata dan 
juga perekonomian (Zulhijahayanti, et al., 2021). Virus Corona yang kini telah tersebar memiliki efek yang sangat mematikan sehingga hal tersebut membuat semua negara dipaksa memberikan kebijakan untuk mengamankan masyarakatnya dari penyebaran virus yang mematikan, jumlah korban yang terus bertambah setiap hari hingga ratusan orang meninggal. Oleh karena itu, Indonesia yang merupakan salah satu negara yang juga terkena dampak penyebaran virus COVID-19 dalam waktu yang dekat akan melakukan berbagai tindakan antisipasi dengan cara menyarankan untuk melakukan pembatasan jarak sampai adanya gagasan untuk dapat bekerja dari rumah, serta semua instansi pelayanan publik harus ditutup terlebih dahulu hingga kondisi membaik (Prasetyo, 2020). Hal ini menyebabkan Virus Corona menghambat segala kegiatan orang (Fitriadi, et al., 2021). Di Indonesia sendiri, banyak analis yang mempercayai bahwa pandemi yang berdampak terhadap pembatasan jalan domestik dan internasional, social distancing, serta karantina massal mulai memengaruhi perekonomian Indonesia pada awal tahun 2020 (Pratama, 2021). Menurut Hanoatubun (2020) Perekonomian termasuk sektor yang terkena dampak signifikan menurun, yang menyebabkan masyarakat Indonesia mayoritas mengalami kesulitan dan berdampak pada pembangunan nasional (Zulkipli \& Muharir, 2021).

Penurunan terjadi secara signifikan pada perekonomian nasional Indonesia, dimana dapat dilihat dari ratusan pemilik UMKM yang telah gulung tikar akibat secara resmi pemerintah telah menyampaikan bahwa masyarakat harus bekerja dari rumah, adanya peraturan bagi tempat pelayanan publik untuk tutup, serta masyarakat diwajibkan untuk memakai masker dan melakukan pembatasan sosial, dan di pertengahan bulan Mei 2020 PSBB (Pembatasan Sosial Berskala Besar) telah diterapkan di Jawa Timur. Walaupun kebijakan tersebut memberi dampak yang kontroversi tetapi karena tujuan pengamanan serta penanganan adanya penyebaran virus, sehingga daerah-daerah yang selama ini menjadi ujung tombak perdagangan di Jawa Timur pun harus terpaksa tidak buka lagi (Wijoyo \& Widiyanti, 2020). Sehingga itu yang membuat kondisi UMKM serta pemilik usaha mikro kecil khususnya di berbagai kota yang menerapkan PSBB, disertai sanksi denda dan pidana seperti Surabaya, Sidoarjo dan Gresik, pelaku usaha kecil khususnya mengalami kelumpuhan dan kebangkrutan (Prasetyo, 2020).

Salah pelaku UMKM yang ikut merasakan dampak bencana pandemi COVID-19 yaitu Pedagang Kaki Lima (PKL) dimana dampaknya cukup signifikan pada pendapatan mereka (Zulhijahayanti, et al., 2021). PKL tidak memiliki perizinan yang resmi, sehingga dampak yang sangat terlihat adalah banyak pedagang yang kehilangan atau berkurangnya penghasilan hingga harus menutup usaha karena adanya pandemi ini. Ali Mahsun sebagai ketua umum DPP Asosiasi Pedagang Kaki Lima (APKLI), menyatakan omzet PKL menurun hingga 80\% selama masa pandemi, dan mengalami kebangkrutan sekitar 40\% (Zulhijahayanti, et al., 2021). Selain itu masalah lain juga dialami oleh UMKM atau usaha mikro, kecil, dan menengah di Jawa Timur dimana mereka mendominasi sektor ekonomi 
sebesar 98,95 persen (BPS Jatim, 2018). Fungsi UMKM di daerah Jawa Timur cukup berpengaruh, buktinya saja perhitungan pada K-UMKM di Jatim menunjukkan pada tahun 2016 UMKM memiliki kontribusi sebanyak 56,43\% dan mengalami peningkatan dengan hasil 56,63\% saat tahun 2017 lalu saat tahun 2018 juga meningkat menjadi 56,93\%, namun ketika mulai berlangsungnya pandemic menjadi menurun sebanyak 27,21\% (Soetjipto, 2020).

Jika dilihat dari berbagai permasalahan di atas, maka seharusnya terdapat strategi yang lebih baru dalam mempertahankan bisnis atau usaha yang terdampak akibat pandemi COVID-19 agar tetap mendapat penghasilan yang sesuai. Menurut penulis, salah satu hal yang bisa dikerjakan yakni dengan mendirikan usaha menggunakan sistem penjualan online atau digital marketing. Ditambah lagi era sekarang sangat pesat dalam perkembangan adanya teknologi informasi, banyak pelaku bisnis dari usaha yang kecil sampai besar menggunakan dan memanfaatkan teknologi untuk menjalankan usahanya, hal ini menyebabkan banyak persaingan ketat antara pelaku bisnis (Gumilang, 2019). Menurut Mannuhung (2018), ilmu dan teknologi yang berkembang pesat ini menuntut agar individu hingga masyarakat siap untuk menghadapi kemajuan tersebut (Lauentinus, et al., 2021). Siap atau tidak sektor UMKM harus melakukan transaksi secara online agar meningkatkan pendapatan selama masa pandemi (Amri, 2020). Selain itu, adanya persaingan dan keadaan yang sulit menjadi pertimbangan bagi para pelaku usaha untuk berusaha memenangkan persaingan tersebut dengan melakukan inovasi (Pradiani, 2017).

Dalam situasi pembatasan kegiatan untuk menekan angka covid-19, maka kegiatan berinteraksi luar ruangan pun berkurang dan pada sektor UMKM yang biasa ramai akhirnya menjadi sepi. Alternatif digital marketing atau online pun menjadi sarana yang baik untuk tetap mempertahankan usaha (Dewi, 2021). Menurut Chaffey (2015), digital marketing sendiri merupakan marketing tradisional yang telah dikembangkan, dimana jika marketing secara tradisional dilakukan dengan cara berkomunikasi secara offline seperti menyebarkan brosur, dan mengiklankan produk di televisi atau radio, sedangkan digital marketing merupakan bentuk onlinenya, dimana komunikasi dilakukan secara online melalui platform sosial media (Gumilang, 2019). Teknik berjualan menggunakan platform media membuat pertukaran informasi dan interaksi sosial menjadi lebih mudah (Sarwono \& Prihartono, 2012).

Digital marketing bisa memberikan kemajuan dalam jual beli dengan memungkinkan individu untuk tetap berjualan tanpa tatap muka dengan orang lain. E-commerce atau marketplace sendiri merupakan perantara yang berpotensi bagi orang yang menjalankan bisnis agar dalam menawarkan produk menjadi menarik pelanggan yang memiliki potensial dari berbagai negara di dunia dan konsumen mendapatkan berbagai model pengetahuan akan produk serta melakukan bertransaksi dengan media daring (Zulhijahayanti, et al., 2021). Selain itu, satu karakteristik pemasaran digital menurut Ali Hasan (2013), yaitu melakukan semua kegiatan bisnis melalui internet untuk tujuan penelitian, analisis dan perencanaan 
untuk menemukan, menarik, dan mempertahankan pelanggan. Sehingga inti dari penggunaan digital marketing adalah menjangkau konsumen melului media-media yang tersedia, dan konsumen yang dimaksud adalah mereka yang berjarak jauh dan yang tidak memungkinkan untuk datang ke tempat (Febriyantoro \& Arisandi, 2018). Dari penjelasan diatas, penulis berniat untuk memberikan pelatihan kepada pelaku PKL dan UMKM di Jawa Timur yang terdampak COVID-19 mengenai strategi pemasaran online sebagai wujud kepedulian kami semua untuk mereka, berharap dapat memberikan pengetahuan mengenai bagaimana cara memasarkan barang atau jasa secara online.

\section{Metode}

Metode dalam penyuluhan kegiatan pengabdian masyarakat ini adalah metode pendidikan masyarakat. Tujuan kami adalah untuk memberikan penyuluhan kepada 5 pedagang yang terdampak COVID19. Dengan begitu, diharapkan penyuluhan ini dapat membantu para pedagang agar lebih memahami kemajuan iptek yang telah meningkat dengan memberikan pelatihan dan penjelasan mengenai sistem online. Pengumpulan data awal kami lakukan dengan cara melakukan wawancara secara langsung dengan pihak terkait, sehingga kami dapat mengetahui beberapa hal mengenai kondisi awal permasalahan yang dialami para pedagang selama masa PPKM (Pemberlakuan Pembatasan Kegiatan Masyarakat) agar penyusunan materi dapat sesuai dengan kebutuhan para pedagang.

Pada kegiatan ini kami melakukan penyuluhan dengan materi mengenai strategi pemasaran secara online. Penyuluhan akan bersifat online menggunakan aplikasi zoom, dengan alasan menghindari kerumunan sesuai anjuran dari pemerintah. Kegiatan ini membutuhkan beberapa hal seperti slide power point. Isi dari power point yang kami berikan yang pertama adalah mengenai pemahaman mengenai PPKM serta dampaknya terhadap pedagang. Kemudian, kami memberikan cara meningkatkan motivasi sehingga dapat lebih membantu para pedagang agar mengetahui apa yang harus mereka lakukan dalam mengatasi penurunan motivasi yang terjadi karena penurunan omset yang mereka dapatkan karena COVID-19. Ketiga, kami memberikan solusi bagi pedagang dengan memberikan pemahaman dan manfaat mengenai sistem online.

Evaluasi dari kegiatan penyuluhan ini adalah perubahan pemahaman para pedagang agar lebih paham dan sadar terhadap kemajuan iptek, sehingga diharapkan para pedagang dapat lebih tertarik untuk memanfaatkan sistem online sebagai media penjualannya dan tidak hanya mengandalkan penjualan dari konsumen yang datang. Evaluasi kegiatan ini kami lakukan dengan metode survei dengan item yang kami buat sendiri berdasarkan dengan materi kegiatan. Survei akan dilakukan secara dua kali, yaitu pada sebelum pemberian materi (pretest) dan setelah pemberian materi (posttest). Indikator keberhasilan pada kegiatan kami adalah adanya perubahan dari hasil tes yang lebih meningkat hasilnya sehingga 
sasaran kami yaitu peningkatan pemahaman (kognitif) para pedagang dapat terbentuk.

\section{Hasil dan Pembahasan}

Kegiatan pengabdian dilakukan dalam satu kali pertemuan pada hari Rabu, 25 Agustus 2021 selama kurang lebih 60 menit. Pertemuan ini dihadiri oleh beberapa pelaku UMKM makanan dari tiga daerah di Jawa Timur, diantaranya Surabaya, Sidoarjo dan Jombang. Semua peserta dipertemukan melalui aplikasi zoom sebagai wadah untuk melakukan pertemuan. Aplikasi tersebut dapat diakses melalui smartphone atau komputer peserta yang ditunjang oleh koneksi internet. Pertemuan ini dilakukan dengan pemberian enam materi terkait dengan strategi pemasaran dengan menggunakan sistem online akibat dampak dari pembatasan aktivitas selama pandemi COVID-19 terhadap penjualan para pelaku UMKM.

Wawancara pertama kami lakukan kepada para pedagang untuk mengetahui pandangan terkait penjualan di masa pandemi COVID-19, pandangan terkait sistem penjualan online atau digital marketing, dan kemauan peserta untuk mengembangkan usaha mereka. Dari wawancara tersebut, didapatkan hasil bahwa selama pandemi COVID-19 terjadi penurunan penjualan oleh para pedagang yang berdampak pada turunnya pendapatan mereka. Hal tersebut menimbulkan penurunan motivasi kerja hingga kurangnya keinginan untuk melakukan pengembangan pada sistem penjualan mereka. Disamping itu, para pedagang menyadari penggunaan dari media sosial sebagai alat pemasarannya agar menjadi lebih efektif. Namun, pandangan yang berbeda dari pedagang tentang kerumitan sistem penjualan online membuat mereka tidak segera merealisasikannya. Oleh karena itu, pada kegiatan ini diberikan beberapa materi kepada para peserta terkait penggunaan digital marketing secara lebih mendalam.

Tabel 1. Rundown Kegiatan

\begin{tabular}{|c|l|l|}
\hline No & \multicolumn{1}{|c|}{ Uraian Kegiatan } & Keterangan \\
\hline 1 & Materi pembuka "Covid dan Dampaknya" & Berhasil \\
\hline 2 & Materi peningkatan motivasi & Berhasil \\
\hline 3 & Materi "Digital Marketing" & Berhasil \\
\hline 4 & Materi "How to be a good Marketing" & Berhasil \\
\hline 5 & Materi Keuntungan Promosi Sosial Media & Berhasil \\
\hline 6 & "Tips Foto Bermodalkan HP?" & Berhasil \\
\hline
\end{tabular}

Pada sesi yang pertama, fasilitator memberikan penjelasan tentang dampak dari COVID-19 terhadap peraturan pembatasan kegiatan masyarakat. Pembatasan ini menyebabkan penurunan jumlah konsumen pada para pedagang kaki lima. 
Kemudian, kepada para peserta dipaparkan tentang peraturan pemerintah dan dampaknya terhadap penurunan motivasi kerja. Sesi kedua, fasilitator menjelaskan mengenai bagaimana meningkatkan motivasi kerja yang dapat dilakukan oleh para pedagang. Fasilitator berfokus pada peningkatan motivasi peserta dengan cara menantang kemampuan diri dalam meningkatkan hasil penjualan mereka. Salah satunya adalah menggunakan sistem penjualan baru menggunakan sosial media.

Sesi ketiga, fasilitator memberikan solusi bagi para pedagang dengan cara menjalankan bisnisnya menggunakan sistem online. Fasilitator menunjukan pilihan ragam aplikasi media sosial yang dapat digunakan sesuai dengan tipe/ bentuk jasa yang ditawarkan. Peserta dapat menentukan aplikasi untuk menunjang sistem penjualannya. Sesi keempat, fasilitator mengedukasi peserta bagaimana cara memasarkan produk makanan dan minumannya di media sosial serta apa saja keuntungan yang diberikan. Sesi selanjutnya fasilitator memfokuskan pembahasan terkait salah satu aplikasi media sosial Instagram dan aplikasi pesan antar online.

Sesi kelima, fasilitator menjelaskan cara membuat aplikasi bisnis Instagram dan GoFood. Beberapa peserta belum mengetahui bagaimana cara pembuatan akun yang dapat menunjang sistem penjualan online. Sesi terakhir, fasilitator memberikan tips atau cara untuk memanfaat HP sebagai media foto produk penjualan. Serta cara pemberian caption yang sesuai dan menarik untuk mencuri perhatian konsumen. Fasilitator mengedukasi peserta tentang teknis pengambilan dan editing foto, hingga proses pengunggahan foto ke media sosial.

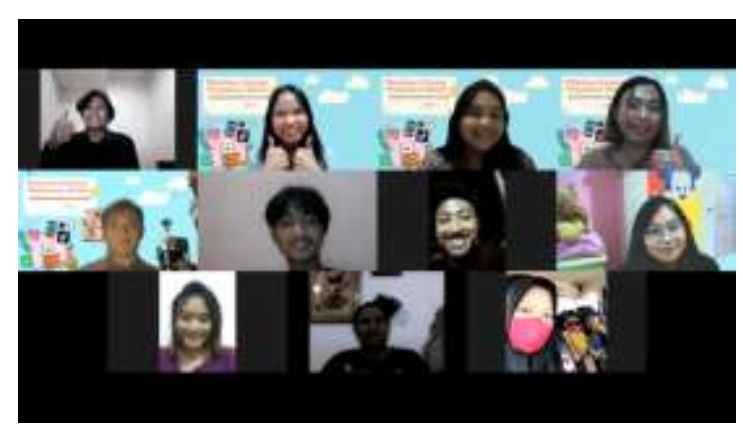

Gambar 1. Foto Bersama



Gambar 2. Penjelasan Materi 
[ 370 ] Adinda Alifia Putri, dkk / To Maega : Jurnal Pengabdian Masyarakat, Vol.4; No.3; Oktober 2021

Tabel 2. Data Karakteristik Partisipan

\begin{tabular}{|l|c|}
\hline \multicolumn{1}{|c|}{ Karakteristik Peserta } & Jumlah \\
\hline Usia & 3 \\
\hline 20-30 Tahun Pekerjaan & 1 \\
\hline 30-40 Tahun & 1 \\
\hline 40-50 Tahun & 1 \\
\hline \multicolumn{2}{|c|}{ Penis Dagangan } \\
\hline Pengusaha & 1 \\
\hline Pedagang & 1 \\
\hline Wiraswasta & 4 \\
\hline Ibu Rumah Tangga & 1 \\
\hline
\end{tabular}

Tabel 3. Hasil Pretest dan Posttest

\begin{tabular}{|c|c|c|c|}
\hline No & Pertanyaan & $\begin{array}{c}\text { Jawaban } \\
\text { Pre-test }\end{array}$ & $\begin{array}{l}\text { Jawaban } \\
\text { Post-test }\end{array}$ \\
\hline \multirow[t]{4}{*}{1.} & \multirow{4}{*}{$\begin{array}{l}\text { Seberapa } \\
\text { penting } \\
\text { penggunaan } \\
\text { sosial media } \\
\text { menurut anda? }\end{array}$} & Sangat penting sekali & $\begin{array}{l}\text { Sangatlah penting. Untuk } \\
\text { menunjang penjualan kami }\end{array}$ \\
\hline & & $\begin{array}{l}\text { Di era saat ini tentu sangat penting } \\
\text { penggunaan media sosial, apalagi } \\
\text { pada pandemi seperti ini yang } \\
\text { apa-apa harus online }\end{array}$ & $\begin{array}{l}\text { Sangat penting, apalagi pada } \\
\text { saat pandemi seperti ini yang } \\
\text { mana sering menggunakan } \\
\text { media online }\end{array}$ \\
\hline & & $\begin{array}{l}\text { Penting si karena kita bisa } \\
\text { membuat pelanggan lebih praktis } \\
\text { dan lebih mudah untuk memesan } \\
\text { dagangan kita cuma dengan } \\
\text { melalui gadget pesanan bisa } \\
\text { diantar kerumah }\end{array}$ & $\begin{array}{l}\text { Sangat penting untuk membantu } \\
\text { penjualan di masa pandemi } \\
\text { seperti ini }\end{array}$ \\
\hline & & $\begin{array}{l}\text { Penting sekali untuk mendapatkan } \\
\text { informasi dan bisa untuk } \\
\text { menawarkan penjualan }\end{array}$ & $\begin{array}{l}\text { Setelah adanya pelatihan ini, sy } \\
\text { sgt merasa bahwa sosial penting } \\
\text { dan digital marketing sgt } \\
\text { membantu }\end{array}$ \\
\hline
\end{tabular}


[ 371 ] Adinda Alifia Putri, dkk / To Maega : Jurnal Pengabdian Masyarakat, Vol.4; No.3; Oktober 2021

\begin{tabular}{|c|c|c|c|}
\hline & & Sekedar untuk hiburan & $\begin{array}{l}\text { Sangat penting supaya } \\
\text { dagangan saya banyak pembeli } \\
\text { baru }\end{array}$ \\
\hline \multirow[t]{5}{*}{2.} & \multirow{5}{*}{$\begin{array}{l}\text { Menurut anda, } \\
\text { apa keuntungan } \\
\text { menggunakan } \\
\text { media sosial } \\
\text { sebagai alat } \\
\text { pemasaran? }\end{array}$} & $\begin{array}{l}\text { Untuk menarik para pelanggan } \\
\text { yang terdampak pandemi /ppkm } \\
\text { ini }\end{array}$ & $\begin{array}{l}\text { Untuk meningkatkan } \\
\text { penghasilan kami serta sebagai } \\
\text { ajang promosi jualan kami }\end{array}$ \\
\hline & & $\begin{array}{l}\text { Keuntungannya kita tidak perlu } \\
\text { capek-capek untuk menawarkan } \\
\text { barang dagangan kita ke rumah- } \\
\text { rumah, produk bisa cepat tersebar } \\
\text { dengan mudah, komunikasi pun } \\
\text { juga mudah }\end{array}$ & $\begin{array}{l}\text { Informasi tentang produk dapat } \\
\text { beredar dengan cepat dan jelas }\end{array}$ \\
\hline & & $\begin{array}{l}\text { Banyak keuntungan yang kita bisa } \\
\text { dapat salah satunya bisa } \\
\text { mempermudah pembeli untuk } \\
\text { memesan dagangan kita }\end{array}$ & $\begin{array}{l}\text { Mudah berinteraksi, } \\
\text { meningkatkan penjualan, } \\
\text { mengurangi biaya yg keluar }\end{array}$ \\
\hline & & $\begin{array}{l}\text { Hampir seluruh orang } \\
\text { menggunakan media sosial, dari } \\
\text { situ orang akan melihat apa yg } \\
\text { kita j }\end{array}$ & $\begin{array}{l}\text { Sangat mudah untuk } \\
\text { berinteraksi dg konsumen, } \\
\text { penggunaan biaya sgt efektif } \\
\text { lalu di masa masa spt ini dpt } \\
\text { mempermudah juga bwt bisa } \\
\text { naikin omset }\end{array}$ \\
\hline & & Menambah omzet & $\begin{array}{l}\text { Menambah konsumen baru dan } \\
\text { meningkatkan omzet }\end{array}$ \\
\hline \multirow[t]{5}{*}{3.} & \multirow[t]{5}{*}{$\begin{array}{l}\text { Bagaimana cara } \\
\text { anda untuk } \\
\text { meningkatkan } \\
\text { jumlah pembeli } \\
\text { saat berjualan? }\end{array}$} & $\begin{array}{l}\text { Saya berinisiatif untuk mendaftar } \\
\text { ke akun sosial media }\end{array}$ & $\begin{array}{l}\text { Cara untuk meningkatkan } \\
\text { jumlah pembeli kita adakan } \\
\text { promosi/diskon misal setiap } \\
\text { pembelian minimal } 5 \text { kita } \\
\text { adakan } 1 \text { gratisan }\end{array}$ \\
\hline & & $\begin{array}{l}\text { Saya membuka banyak reseller } \\
\text { dengan begitu penjualan akan } \\
\text { lebih cepat dan mudah }\end{array}$ & Menggunakan media online \\
\hline & & $\begin{array}{l}\text { Berpromosi melalui sosmed/ non } \\
\text { sosmed }\end{array}$ & $\begin{array}{l}\text { Membuat akun di seluruh sosial } \\
\text { media, mendaftar di ojek online }\end{array}$ \\
\hline & & $\begin{array}{l}\text { Menawarkan dagangan melalui } \\
\text { media sosial }\end{array}$ & $\begin{array}{l}\text { Memanfaatkan sosial media dan } \\
\text { berjualan secara online }\end{array}$ \\
\hline & & Mempromosikan ke tetangga & Mendaftarkan ke gofood \\
\hline \multirow[t]{2}{*}{4.} & & Belum & $\mathrm{Ya}$ \\
\hline & & Belum & $\begin{array}{l}\text { YA, seperti shopee food, } \\
\text { grabfood dan gofood }\end{array}$ \\
\hline
\end{tabular}


[ 372 ] Adinda Alifia Putri, dkk / To Maega : Jurnal Pengabdian Masyarakat, Vol.4; No.3; Oktober 2021

\begin{tabular}{|c|c|c|c|}
\hline & \multirow{3}{*}{$\begin{array}{l}\text { Apakah anda } \\
\text { pernah } \\
\text { melakukan } \\
\text { inovasi baru } \\
\text { dalam } \\
\text { berjualan? } \\
\text { Sebutkan jika } \\
\text { "YA" }\end{array}$} & $\begin{array}{l}\text { Iya } \\
\text { Dengan menambahkan menu } \\
\text { menu baru }\end{array}$ & $\begin{array}{l}\text { Ya, memberikan diskon atau } \\
\text { promo }\end{array}$ \\
\hline & & Belum & YA \\
\hline & & Belum & Ya \\
\hline \multirow[t]{5}{*}{5.} & \multirow{5}{*}{$\begin{array}{l}\text { Bagaimana cara } \\
\text { agar barang } \\
\text { dagangan / } \\
\text { jualan anda } \\
\text { menarik dalam } \\
\text { sistem } \\
\text { penjualan } \\
\text { online? }\end{array}$} & $\begin{array}{l}\text { Memberikan diskon setiap } \\
\text { pembelian }\end{array}$ & Diskon dan foto menarik \\
\hline & & $\begin{array}{l}\text { Membuat promo, lalu } \\
\text { menyebarkannya lewat social } \\
\text { media }\end{array}$ & $\begin{array}{l}\text { Menggunakan feeds yang } \\
\text { menarik dan memberikan } \\
\text { diskon }\end{array}$ \\
\hline & & $\begin{array}{l}\text { Dengan di foto sebagus mungkin } \\
\text { dan memberikan caption yang } \\
\text { menarik }\end{array}$ & $\begin{array}{l}\text { Dengan memberikan promo } \\
\text { atau diskon, menampilkan foto } \\
\text { semenarik mungkin agar } \\
\text { pembeli tertarik. }\end{array}$ \\
\hline & & Menawarkan promo atau diskon & $\begin{array}{l}\text { Dengan cara memberikan } \\
\text { promosi yang menarik dan foto } \\
\text { semenarik mungkin }\end{array}$ \\
\hline & & Foto produk yg menarik & $\begin{array}{l}\text { Dengan memfoto makanan } \\
\text { dengan baik dan menarik }\end{array}$ \\
\hline 6. & $\begin{array}{l}\text { Platform sosial } \\
\text { media manakah } \\
\text { yang menurut } \\
\text { anda cocok } \\
\text { digunakan } \\
\text { untuk } \\
\text { penjualan? }\end{array}$ & $\begin{array}{l}60 \% \text { GO-FOOD/ GRAB-FOOD / } \\
\text { SHOPEE FOOD } \\
20 \% \text { Instagram dan WhatsApp } \\
20 \% \text { Instagram }\end{array}$ & $\begin{array}{l}80 \% \text { GO-FOOD/ GRAB-FOOD } \\
\text { / SHOPEE FOOD } \\
20 \% \text { Instagram }\end{array}$ \\
\hline \multirow[t]{4}{*}{7.} & \multirow[t]{4}{*}{$\begin{array}{l}\text { Menurut anda, } \\
\text { apa itu Digital } \\
\text { Marketing? }\end{array}$} & $\begin{array}{l}\text { Suatu strategi pemasaran dengan } \\
\text { menggunakan media digital }\end{array}$ & $\begin{array}{l}\text { Suatu ajang pemasaran yang } \\
\text { menggunakan internet atau } \\
\text { digital }\end{array}$ \\
\hline & & $\begin{array}{l}\text { Suatu kegiatan promosi sebuah } \\
\text { produk dengan bantuan internet } \\
\text { agar mendapat konsumen yang } \\
\text { lebih banyak }\end{array}$ & Menjual dagangan lewat online \\
\hline & & Tidak tahu & $\begin{array}{l}\text { Penggunaan sosial media } \\
\text { sebagai media penjualan }\end{array}$ \\
\hline & & $\begin{array}{l}\text { Penjualan melalui online atau } \\
\text { media sosial }\end{array}$ & $\begin{array}{l}\text { Pemanfaatan teknologi saat ini } \\
\text { untuk penjualan agar dapat } \\
\text { meningkat konsep pemasaran } \\
\text { itu sendiri }\end{array}$ \\
\hline
\end{tabular}

(C) To Maega / Jurnal Pengabdian Masyarakat. This is an open access article under the CC BY-SA 4.0 license (https://creativecommons.org/licenses/by-sa/4.0/). 
[ 373 ] Adinda Alifia Putri, dkk / To Maega : Jurnal Pengabdian Masyarakat, Vol.4; No.3; Oktober 2021

\begin{tabular}{|c|c|c|c|}
\hline & & Jualan online & Jualan online \\
\hline \multirow[t]{5}{*}{8.} & \multirow{5}{*}{$\begin{array}{l}\text { Apa hal penting } \\
\text { yang harus } \\
\text { dilakukan saat } \\
\text { menggunakan } \\
\text { sistem } \\
\text { penjualan } \\
\text { secara online? }\end{array}$} & Memberi kualitas yang bagus & $\begin{array}{l}\text { Kita buat konsumen itu menarik } \\
\text { dagangan kita misal kita buat } \\
\text { foto barangjualan kami }\end{array}$ \\
\hline & & $\begin{array}{l}\text { Merespon, memperhatikan setiap } \\
\text { pesanan dengan baik dan cepat }\end{array}$ & Teliti dan cermat \\
\hline & & $\begin{array}{l}\text { Menjamin produk Sampai } \\
\text { ditangan costumer dengan aman } \\
\text { dan cepat }\end{array}$ & $\begin{array}{l}\text { Membuat foto penjualan } \\
\text { semenarik mungkin, tetap } \\
\text { menjaga kualitas produk }\end{array}$ \\
\hline & & $\begin{array}{l}\text { Menawarkan promo, membuat } \\
\text { video penawaran yg menarik }\end{array}$ & $\begin{array}{l}\text { Memahami aplikasi dan } \\
\text { beberapa persyaratan yang } \\
\text { akan dipilih untuk dijadikan } \\
\text { tempat berjualan }\end{array}$ \\
\hline & & Foto produk dan harga & Foto produk \\
\hline 9. & $\begin{array}{l}\text { Apakah anda } \\
\text { tertarik untuk } \\
\text { melakukan } \\
\text { penambahan } \\
\text { dan/ perubahan } \\
\text { pada sistem } \\
\text { penjualan anda? }\end{array}$ & $\begin{array}{l}60 \% \text { Ya } \\
20 \% \text { Tidak } \\
20 \% \text { Mungkin }\end{array}$ & $\begin{array}{l}80 \% \text { Ya } \\
20 \% \text { Mungkin }\end{array}$ \\
\hline
\end{tabular}

Sebelum dilakukan pertemuan dengan para pedagang UMKM, hasil pre-test menunjukan bahwa para pedagang mengetahui kegunaan pemakaian media sosial, tetapi hingga saat ini hanya digunakan sebagai media hiburan dan tidak dipergunakan untuk kepentingan penjualan produk mereka. Para pedagang ini menjawab bahwa digital marketing hanya merupakan wadah promosi yang dilakukan secara online yang dapat mempermudah penjual dengan berfokus pada respon konsumen nantinya, seperti membuat foto dan harga yang menarik serta memastikan produk yang sampai sesuai dengan ekspektasi mereka. Terkait dengan cara meningkatkan penjualan, rata-rata partisipan menjawab dapat dilakukan promosi secara online maupun melalui pengenalan produk ke tetangga dan pemilihan aplikasi pesan antar menjadi pilihan terbanyak yang dipilih sesuai dengan kebutuhan saat ini. Namun, partisipan mengatakan belum memiliki inovasi yang dilakukan dalam meningkatkan penjualan mereka, begitu pula untuk membuat akun pada aplikasi-aplikasi untuk menunjang sistem penjualan mereka.

Setelah melakukan pertemuan, peserta diberikan post-test untuk mengetahui pengetahuan yang telah dimiliki oleh para peserta UMKM. Ditemukan hasil bahwa pemahaman mereka memiliki peningkatan. Tergambar melalui pandangan 
mengenai penggunaan digital marketing yang tidak hanya dipergunakan untuk mempermudah pedagang, tetapi bisa menjadi wadah dalam menyebarkan informasi terkait produk lebih detail, interaksi antar pedagang-konsumen menjadi lebih mudah, penggunaan biaya menjadi lebih efektif hingga mampu menaikan omset penjualan. Para pedagang UMKM sendiri belum memfokuskan aplikasi penunjang sistem penjualan mereka. Namun, kini mereka sudah mendapatkan pandangan terkait apa yang perlu dilakukan dalam menarik perhatian calon konsumen. Dengan memanfaatkan penggunaan aplikasi yang sesuai dengan jasa/produk yang mereka tawarkan, dan penggunaan diskon atau promo, serta mengelola akun mereka agar menjadi menarik dan informatif terkait dengan produk yang dimiliki. Penggunaan pada jasa layanan pesan antar pun menjadi pilihan pada pedagang UMKM yang dapat dijadikan sebagai salah satu inovasi yang mereka pilih.

Pada indikator keberhasilan ini, ditemukan adanya peningkatan pemahaman oleh para partisipan sebagai pedagang UMKM terkait dengan penggunaan digital marketing. Hal ini digambarkan melalui penjelasan mereka pada hasil post-test. Digital marketing tidak hanya untuk menarik konsumen, tetapi dapat dijadikan sebagai alat bantu penjualan terkait dengan hubungan antara penjual dan pembeli. Dimana para pedagang dapat menerima masukan langsung dari konsumen melalui fitur chat. Mengingat dampak dari peraturan akibat COVID-19 terkait larangan makan ditempat, menjadikan penjual kurang dapat berinteraksi secara langsung dengan calon pembeli. Pemahaman mereka juga meningkat terkait penjualan yang dapat dilakukan dengan berbagai macam cara, seperti menentukan penggunaan aplikasi sesuai jasa maupun produk yang ditawarkan, penggunaan diskon juga menjadi faktor menarik bagi calon konsumen dengan harga yang lebih murah, serta kemenarikan pemberian informasi terkait deskripsi produk yang dapat menarik perhatian calon konsumen.

Tertariknya partisipan untuk memulai menggunakan media sosial merupakan pencapaian dalam kegiatan ini. Hal tersebut telah memenuhi indikator keberhasilan terkait dengan adanya peningkatan pemahaman pedagang akan kemajuan teknologi. Sehingga mampu menarik minat partisipan dalam memanfaatkan media sosial sebagai penunjang sistem bisnis mereka. Tidak hanya itu, dalam pelaksanaan ini ditemukan beberapa hal lain yang juga penting untuk ulas.

Dalam pelaksanaan ini ditemukan beberapa hal lain terkait kelebihan dan kelemahannya. Keunggulan dari pelaksanaan ini adalah dapat menjadi pemahaman mendalam akan pentingnya penggunaan digital marketing dikala pandemi COVID19. Dengan begitu, calon konsumen dipermudah untuk menemukan informasi yang mereka perlukan, dari bentuk promosi yang telah dilakukan. Sedangkan kelemahan dalam pelaksanaan kegiatan ini, berupa fasilitator tidak dapat menjangkau lokasi partisipan secara langsung. Dimana mengetahui respon peserta atau mengenal satu sama lain menjadi terbatas, ketika peserta tidak mengaktifkan kamera. Fasilitator tidak menjamin apakah peserta memahami dan mengaplikasikan materi dalam 
kehidupan nyata. Adanya kendala waktu yang dimiliki peserta yang berbeda-beda, sehingga pada saat melakukan pertemuan zoom beberapa peserta masih ada yang melakukan proses berdagangnya. Selain itu, terkait kurangnya pemahaman oleh beberapa peserta tentang aplikasi yang digunakan untuk melakukan pertemuan.

\section{Kesimpulan}

Berdasarkan hasil dan pembahasan yang sudah dipaparkan, dapat disimpulkan bahwa hasil yang didapat sesuai dengan indikator keberhasilan pelatihan, yaitu para peserta pelatihan diharapkan lebih menyadari akan pentingnya pemahaman digital marketing. Setelah mengikuti pelatihan, para peserta diharapkan memiliki atau mengalami peningkatan akan kesadaran diri mengenai bagaimana memaksimalkan sosial media sebagai sarana untuk berdagang. Berdasarkan dari hasil posttest, peserta pelatihan mengalami peningkatan pemahaman tentang bagaimana memanfaatkan sosial media bukan hanya untuk hiburan semata, namun juga sebagai wadah mereka berjualan. Para peserta juga memiliki wawasan baru seperti fitur chat, untuk menyiasati pandemi COVID-19 yang mengganggu komunikasi para peserta dengan pelanggan. Meskipun belum semua peserta yakin akan menggunakan aplikasi tertentu, tetapi mereka sudah memahami bagaimana cara menarik pelanggan dalam dunia digital marketing seperti pemilihan foto yang menarik \& memberikan promo-promo yang menarik.

\section{Ucapan Terimakasih}

Kami selaku kelompok pengabdian mengucapkan terima kasih kepada ibu Johanna Natalia, S.Psi., M.Mus., Ph.D. selaku dosen pembimbing kami, selanjutnya kepada kak Rahma Dianti selaku kakak pendamping kami yang senantiasa selalu membantu kami dalam proses pengerjaan jurnal dan selalu memberikan dukungan kepada kami, dan yang terakhir kepada para peserta pelatihan yang bersedia menjadi partisipan aktif selama kegiatan pelatihan berlangsung dari awal hingga akhirnya kegiatan pengabdian ini.

\section{Daftar Pustaka}

Abidin, M. (2015). Kebijakan fiskal dan peningkatan peran ekonomi umkm. Kemenkeu.

Amri, A. (2020). Dampak covid-19 terhadap UMKM di Indonesia. Jurnal Brand.

Aisyah, S. (2020). Dampak pandemi covid-19 bagi umkm. UINSU.

BPS Jatim. (2018). Analisis hasil se2016 lanjutan potensi peningkatan kinerja usaha mikro kecil provinsi jawa timur, PT. Sinar Murni Indoprinting, Surabaya.

Bahtiar, R. A. (2021). Dampak pandemi covid-19 terhadap sektor usaha mikro, kecil dan menengah serta solusinya. Bidang Ekonomi dan Kebijakan Publik.

Chaffey, D. (2015). Managing digital marketing in 2015. Technology For Marketing \& Advertising. 
Dewi, C. R. (2021). Upaya pengembangan dan pemasaran UMKM dalam menjaga stabilitas perekonomian masyarakat desa akibat pandemi covid-19. JAMAIKA: Jurnal Abadi Masyarakat.

Febriyantoro, M. T., \& Arisandi, D. (2018, December). Pemanfaatan digital marketing bagi usaha mikro, kecil dan menengah pada era masyarakat ekonomi asean. JMD: Jurnal Manajemen Dewantara, 1, 62-76.

Fitriadi, Y., Novita, W., \& Edriani, D. (2021, February). Ekonomi kreatif sebagai solusi bagi keluarga pra sejahtera untuk bertahan dalam era new normal. To Maega, 4, 35-46.

Gumilang, R. R. (2019). Implementasi digital marketing terhadap peningkatan penjualan hasil home industri. Jurnal Ilmiah Manajemen, 10.

Lauentinus, Rizan, O., Hamidah, \& Sarwindah. (2021, February). Digitalisasi umkm berbasis retail melalui program hibah ristek-brin. To Maega, 4, 1-13.

Pradiani, T. (2017). Pengaruh Sistem Pemasaran Digital Marketing Terhadap Peningkatan Volume Penjualan Hasil Industri Rumahan. Jurnal Jibeka, 11(2), 46-53.

Prasetyo, P. E. (2020). Peran usaha kecil dan menengah (umkm) dalam kebijakan penanggulangan kemiskinan dan pengangguran. Akmenika UPY, 13.

Pratama, B. C., Innayah, M. N., \& Darmawan , A. (2021). Pendampingan umkm dan pedagang kaki lima (pkl) terdampak covid-19 di area kampus universitas muhammadiyah purwokerto dalam menjalankan contactless business. Jurnal Budimas.

Richards, C. (2008). Crisis management: operating inside their ooda loops. Atlanta: First Adaptive Leadership Symposium.

Sarwono, J., \& Prihartono, K. (2012). Perdagangan online: cara bisnis di internet. Jakarta: PT Elex Media Komputindo.

Siegel, \& Andrew, F. (2000). Practical business statistic. New York: IrwinMcGraw Hill.

Soetjipto, N. (2020). Ketahanan umkm jawa timur melintasi pandemi covid-19. Yogyakarta: K-Media.

Tambunan, T. T. (2002). Usaha kecil dan menengah di indonesia;beberapa isu penting. Jakarta: Salemba Empat.

Wijoyo, H. (2020). Digitalisasi umkm pasca pandemi covid-19 di riau. Prosiding Konferensi Nasional Administrasi Negara Sinagara.

Wijoyo, H., \& Widyanti, W. (2020). Digitalisasi usaha mikro kecil dan menengah (umkm) di era pandemi-19. Seminar Nasional Kahuripan New Normal For New Research: Inovasi Penelitian \& Pengabdian Unggulan. Retrieved Oktober 24, 2020

Zulhijahayanti, H., Safira, K. A., Saputri, L. L., \& Permana, E. (2021). Strategi mempertahankan usaha pedagang kaki lima (pkl) di masa pandemi covid19. Inovasi Jurnal Ilmiah Manajemen.

Zulkipli, \& Muharir. (2021). Dampak covid-19 terhadap perekonomian Indonesia. JIMESHA: Jurnal Ilmiah Mahasiswa Ekonomi Syariah. 